\title{
MACROECONOMIC VARIABLES AND VOLUME OF TRANSACTIONS ON TEHRAN STOCK EXCHANGE
}

\author{
VARIABLES MACROECONÓMICAS Y VOLUMEN DE TRANSACCIONES EN LA \\ BOLSA DE VALORES DE TEHERÁN
}

\author{
Farzaneh Haghighat $\mathrm{Nia}^{1} *$ (D); Naser Shams Gharneh ${ }^{1}$ (D). \\ 1. Amirkabir University of Technology (Polytechnic), Tehran, Iran. \\ *Corresponding author: Farzaneh Haghighat-Nia, email: f.haghighat67@gmail.com
}

\begin{abstract}
This paper examines the relationship between the volume of transactions and macroeconomic variables on the Tehran Stock Exchange. We are collect data for variables such as liquidity, inflation, exchange rate, the total value of imports and GDP for ten years period of 2009-2019. For analysis of data, have been used regression analytical method and ordinary least squares method (OLS) model. The results indicate that there are relationships between the macroeconomic variables of liquidity, inflation rate, and GDP with the volume of transactions. Therefore, the relationship between the volume of transactions with liquidity and GDP is positive and significant and with inflation is negative.
\end{abstract}

Keywords: Stock Exchange; volume of transactions; liquidity; inflation.

Cómo citar:

Haghighat Nia, Farzaneh; Shams Gharneh, Naser. (2021). Macroeconomic variables and volume of transactions on tehran stock exchange. Revista de Investigaciones Universidad del Quindio, 33(2), 163-173. https://doi.org/10.33975/riuq.vol33n2.472

Información del artículo: Recibido: 6 mayo 2021; Aceptado: 23 agosto 2021 


\section{RESUMEN}

Este artículo examina la relación entre el volumen de transacciones y las variables macroeconómicas en la Bolsa de Valores de Teherán. Recogemos datos para variables como liquidez, inflación, tipo de cambio, valor total de las importaciones y PIB para el período de diez años 2009-2019. Para el análisis de los datos, se ha utilizado el método analítico de regresión y el modelo del método de mínimos cuadrados ordinarios (MCO). Los resultados indican que existen relaciones entre las variables macroeconómicas de liquidez, tasa de inflación y PIB con el volumen de transacciones. Por tanto, la relación entre el volumen de transacciones con liquidez y el PIB es positiva y significativa y con la inflación es negativa.

Palabras clave: Bolsa de Valores; volumen de transacciones; liquidez; inflación.

\section{INTRODUCTION}

In the economic literature, financial markets play a vital role in economic growth, job creation, investment, stabilization of monetary and financial variables, and overall welfare improvement. In a general classification, financial markets can be classified into two markets: 1 . Money Market and 2. Capital Market.

The capital market plays a key role in economic growth through facilitating corporate financing, optimal allocation of resources, improving the liquidity of assets, and improving corporate governance. Therefore, considering the important role of the capital market, especially the stock exchange in the economic growth of the country and also the channel of communication between this sector and economic institutions, it is important to pay attention to the factors affecting the performance of the stock exchange.

In studying the behavior of factors affecting the economy, the search for a variable or variables that can explain the relationship between the financial sectors of the economy is very important. Money and capital markets, as the pillars of the financial sector, are responsible for providing resources for the economy to turn. Meanwhile, the stock market increases the volume of investment in society by attracting and using stagnant capital; also, the entry of the private sector in economic activities in Tehran had a significant impact on increasing the volume of stock exchange transactions.

The Tehran Stock Exchange (TSE) began operation in early 1969, dealing in shares of a limited number of private banks, industrial companies, Treasury bonds, and state-backed securities. During the 1970s, and especially after the 1974 oil price explosion, the market indicates a demonstrative rise in volume of transactions with modest share price rise. After the Islamic revolution, while Iran/Iraq war of 1979-88, has hardly affected the overall economic conditions, the TSE experienced a period of relative standstill. However, following the ceasefire with Iraq and the first five-year plan that launched a privatization program, the dormant equities market enjoyed a favorable boost and a welcome boon to the exchange's upswing. Afterwards, the Tehran stock market has experienced boom-bust cycles in both trading volume and market value, partly attributed to macroeconomic fluctuations.

Tehran Stock Exchange Organization started its activity in 1990 in line with the macroeconomic policies of the government to attract people's participation in investment, direct stagnant and unproductive capital to productive economic activities, meet the financial needs of manufacturing enterprises and consequently provide Commodities needed by the society. Due to the post-war economic conditions and the impact of changes resulting from macroeconomic 
variables such as inflation and exchange rates on the stock market index, the trading volume of this market has witnessed many fluctuations.

The volume of transactions in the stock market shows the success of the country's capital market. In any investment decision, two factors are very important and are the basis of the investment. These two factors are risk and return. Systematic risk (market risk) is due to environmental conditions and management has no control over it. It seems that in Tehran, systematic risk is high due to many changes in environmental factors, and this necessitates the study of macroeconomic variables, which are among the most important environmental factors affecting the stock market.

At the same time, economic variables affect stock pricing and this will affect the volume of stock transactions. The correct orientation of economic developments will lead to a boom in the capital market so that the supply and demand of funds in the market is more efficient than before.

Therefore, considering the role of government in managing the economy and decisions and the strong impact of government policies on the stock market, it can be concluded that the study of the impact of macroeconomic factors on the volume of stock transactions, can be a new breakthrough for investors and shareholders in understanding the effects of macroeconomic decisions on trading volume and stock prices.

In the following, the background of studies has been reviewed. After that, the model used in this paper is defined. Other parts include the results of model implementation, conclusions and future suggestions.

\section{REVIEW OF LITERATURE}

The effect of macroeconomic variables such as liquidity, inflation rate, exchange rate, the total value of imports, and GDP on stock trading volume has been accepted as a theory. However, in the last decade, attempts have been made to study the impact of economic variables theoretically and to measure their effects empirically.

The research is based on the theory that stock prices reflect the present value of the future cash flows of that stock. Economic variables affect both future cash flows and expected rates of return. Therefore, they can affect stock prices and trading volume.

Moses (1995) examined four Asian markets, including Malaysia, the Philippines, Singapore, and Thailand, using monthly data from 1985 to 1993, and found evidence for a relationship between the volume and absolute magnitude of price fluctuations in all markets but the Philippines.

Glenor Muradoglu and Matin (1996) investigated the return of the Istanbul Stock Exchange on a monthly basis using interest rate, exchange rate, inflation and money supply variables for the period 1986 to 1993 . The implementation of the Engel-Granger method and the Johansson method showed that the stock price index has a long-term relationship with monetary variables; So that the relationship between the stock price index and the money supply is positive, but its relationship with the exchange rate, interest rate and inflation rate are negative.

Kahn and Shen (1999) applied Granger causality tests and Engel-Granger method to the vector error correction model and found that the Korean stock market was characterized by economic variables such as production index, exchange rate and trade balance.

Chen (2001) examined the relationship between stock returns and trading volume using daily data from nine major world markets (New York, Tokyo, London, Paris, Toronto, Milan, Zurich, Amsterdam, and Hong Kong). He provides strong evidence that in eight of the nine markets, Granger causality returns are the volume of trading. 
Lee (2002) studied the dynamic relationship between volume and return in the three major stock markets of New York, Tokyo and London; and found evidence that in the US and Japan, Granger causality returns are the volume of trading. Granger causality from volume to returns was not observed in any of the countries.

Christopher Gann et al. (2006) tested the interactions between the New Zealand Stock Index and a set of seven macroeconomic variables for monthly data from January 1990 to January 2003 using aggregate tests. Economic variables used included inflation, exchange rates, GDP, money supply, long-term interest rates, shortterm interest rates, and the retail price of local oil. The results of the Johansson test show that there is a long-run relationship between the New Zealand share price index and the economic variables tested.

Shahnaz Mashayekh et al. (2011) investigated the relationship between a set of economic variables include inflation rate, interest rate of one-year investing deposits in state banks, interest rate of bonds and the growth rate of gold price with Tehran Stock Exchange (TSE) indicators during April 1998 to March 2008. The findings showed that the relationship between inflation rate and stock return as well as growth rate of Tehran Stock Market transactions volume in long term is positive and meaningful. Moreover, The results indicated that an increase in bank interest rate through drawing investments results in a reduction in the stock transactions volume growth and return and vice versa. So, stock and money markets can be considered as two competing and supplementary markets in the long run. The results of vector-error correction model showed that in short run, gold market could be a substitute for stock market and gold return has an important role in explaining the stock market trend, but this relationship is not meaningful in the long run.

Ali Hasanzadeh and Mehran Kianvand (2012) examined the effects of selected macroeconomic variables on the stock market index in Iran. The relationships between the Tehran Stock Index (TSI) and five macroeconomic variables which consist of gross domestic product, nominal effective exchange rate, money supply, gold coin price and investment in housing sector examined from 1996 to 2008. Results showed that Iran's stock market index is positively influenced by the growth rate of the GDP, the money supply and negatively affected by the gold prices, the private sector investment in housing sector and the nominal effective exchange rate.

Oma and Peter Moreau (2014) analyzed the impact of macroeconomic variables on stock returns in Kenya from 2003 to 2013, using the Arbitrage Pricing Theory (APT) framework and the Capital Asset Pricing Model (CAPM) framework for monthly data. The conventional least squares (OLS) technique has been used to test the validity of the model and the relative importance of the various variables that may affect stock returns. The experimental analysis had interesting results that showed with the exception of interest rates, there is a significant relationship between stock market returns and macroeconomic variables. According to the study, money supply, exchange rates and inflation affect stock market returns in Kenya.

Fadaei Nejad and Farahani (2017) investigated the effect of economic variables on the total stock market index Using the data of the Tehran Stock Exchange index and variables such as consumer price, bank interest rate, gold price, industrial production index, oil price, stock price volatility, exchange rate, money supply. The results showed that the share of these variables in changes in the total stock market index is small. The relationship between volume and efficiency in some emerging markets has also been studied, which presents different results than developed markets.

Nijam et al. (2018) studied the relationship between macroeconomic factors and stock market performance (Sri Lanka). This study 
examined the relationship between the stock price index and five macroeconomic variables from 1980 till 2012. The research results showed that macroeconomic variables and the stock market index in Sri Lanka are significantly related.

According to the studies conducted in the literature review discussion, it was found that no research has been done on the impact of economic factors on the volume of transactions on the Tehran Stock Exchange.

Of course, a lot of research has been done to examine the relationship between trading volume and macroeconomic variables on the stock returns or stock market indices at home and abroad. In this study, the effect of macroeconomic variables such as liquidity, inflation rate, exchange rate, the total value of imports, and GDP on the volume of stock transactions in the Tehran Stock Exchange is investigated.

\section{DATA AND METHODOLOGY}

In this research, using previous studies, the desired variables are extracted and using regression model with statistical methods the significance of each variable on trading volume is analyzed.

In this study liquidity, inflation, exchange rate, the total value of imports and GDP are independent variables and trading volume is used as a dependent variable. Also, due to the correlation between the above variables and exports, this variable was excluded from this study. The data have been collected quarterly for the period of 2009-2019.

\section{Model}

The relationship between the dependent variable and the independent variables is considered logarithmically. For data analysis have been used, regression analytical method and ordinary least squares method (OLS).
The experimental model is defined as follows:

Ln Turnover $=\mathrm{C}+\mathrm{B} 1$ Ln Liquidity + B2 Ln Inflation + B3 Ln Currency + B4 Ln Import + B5 Ln GDP

\section{Stationary test}

In this study, before the implementation of the model, the Stationary of the data was examined. The results of the Stationary test show that all variables are non-stationer in the first level and need a two-level Finite Difference Method.

\section{Checking the assumption of normality of residual}

The normality of residual statements is necessary to examine the estimated OLS parameters.

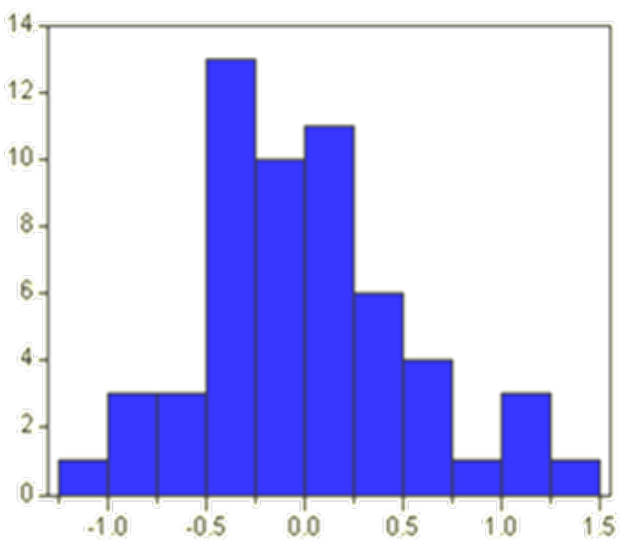

FIG.1. Distribution of residual statements

As can be seen, the residuals have a normal distribution with a good approximation. Therefore, we can examine the significance of variables.

\section{RESULT}

The preliminary results obtained from the implementation of the model are as follows. The Goodness of fit coefficient is $90 \% \approx 89.9 \%$. 
TABLE 1. Model results.

\begin{tabular}{|l|c|c|c|c|}
\hline \multicolumn{1}{|c|}{ Variable } & Coefficient & Std. Error & t-Statistic & Prob. \\
\hline LIQUIDITY & 1.850947 & 0.496611 & 3.727157 & 0.0005 \\
\hline INFLATION & -1.104222 & 0.304296 & -3.628781 & 0.0007 \\
\hline IMPORT & -0.621692 & 0.469221 & -1.324947 & 0.1912 \\
\hline GDP & 0.558435 & 0.201376 & 2.773097 & 0.0078 \\
\hline CURRENCY & -0.701340 & 0.511603 & -1.370869 & 0.1765 \\
\hline C & -12.01590 & 3.675789 & -3.268931 & 0.0020 \\
\hline R-squared & 0.898573 & F-statistic & 88.59280 \\
\hline Adjusted R-squared & 0.888430 & \multicolumn{2}{|l}{} \\
\hline Durbin-Watson stat & 1.011658 & \multicolumn{2}{|l|}{ Prob (F-statistic) } \\
\hline
\end{tabular}

Ref: Field of Survey

Examining the governing assumptions in the least square model

After implementation of the model, the governing assumptions in the least square model include collinearity, Homoscedasticity and autocorrelation should be examined and corrected to avoid wrong answers to hypotheses.

\section{- Collinearity of explanatory variables}

According to the P-Value in Table (1), some variables are not significant. Also, the $\mathrm{F}$ and P-Value functions obtained for the whole regression represent the significance of regression; so there is a problem of Collinearity in the model. Also, considering the P-Value $<0.05$ for the variables of liquidity, inflation and GDP, the null hypothesis in relation to the meaninglessness of coefficients is rejecting and the significance of these coefficients is accepting at a $95 \%$ of confidence level.

After examining the variables, it was found that the exchange rate variable is strongly Collinear with the liquidity and inflation rate, and the import variable is strongly Collinear with the liquidity, inflation rate and GDP. The results for the Collinearity of exchange rate and import are shown below, respectively.

TABLE 2. Collinearity of exchange rate variables with inflation and liquidity.

\begin{tabular}{|l|c|c|c|c|}
\hline \multicolumn{1}{|c|}{ Variable } & Coefficient & Std. Error & t-Statistic & Prob. \\
\hline LIQUIDITY & 0.226292 & 0.021228 & 10.66029 & 0.0000 \\
\hline INFLATION & -0.183593 & 0.062999 & -2.914197 & 0.0052 \\
\hline C & 6.53261 & 0.362746 & 18.00879 & 0.0000 \\
\hline R-squared & 0.740070 & \multicolumn{2}{|c|}{ F-statistic } & 75.45056 \\
\hline Adjusted R-squared & 0.730261 & \multicolumn{2}{|c}{ Prob(F-statistic) } & 0.000000 \\
\hline Durbin-Watson stat & 0.131452 & \multicolumn{3}{|c}{} \\
\hline
\end{tabular}

Ref: Field of Survey

TABLE 3. Collinearity of import variables with liquidity, inflation and GDP.

\begin{tabular}{|l|l|l|l|l|}
\hline Variable & Coefficient & Std. Error & t-Statistic & Prob. \\
\hline LIQUIDITY & 0.958866 & 0.050056 & 19.15573 & 0.0000 \\
\hline INFLATION & -0.355463 & 0.068699 & -5.174191 & 0.0000 \\
\hline GDP & 0.151058 & 0.055097 & 2.741662 & 0.0084 \\
\hline C & -2.51282 & 0.409985 & -6.129053 & 0.0000 \\
\hline R-squared & 0.979995 & F-statistic & 849.1380 \\
\hline Adjusted R-squared & 0.978841 & Prob(F-statistic) & 0.000000 \\
\hline Durbin-Watson stat & 1.314787 & \multicolumn{3}{l}{} \\
\hline
\end{tabular}

Ref: Field of Survey 
Therefore, to eliminate Collinearity, the two variables of exchange rate and import were removed from the model. The results obtained after removing these variables indicate that the Collinearity problem is solved:

TABLE 4. Results of model implementation after solving the Collinearity problem.

\begin{tabular}{|l|l|l|l|l|}
\hline Variable & Coefficient & Std. Error & t-Statistic & Prob. \\
\hline LIQUIDITY & 1.125248 & 0.171041 & 6.578804 & 0.0000 \\
\hline INFLATION & -0.755926 & 0.234744 & -3.220219 & 0.0022 \\
\hline GDP & 0.428368 & 0.188266 & 2.275333 & 0.0270 \\
\hline C & -14.96406 & 1.400910 & -10.68168 & 0.0000 \\
\hline R-squared & 0.891742 & F-statistic & 142.7773 \\
\hline Adjusted R-squared & 0.885496 & Prob(F-statistic) & 0.000000 \\
\hline Durbin-Watson stat & 1.016176 & \multicolumn{5}{l}{} \\
\hline
\end{tabular}

\section{- Homoscedasticity}

This article, examine Homoscedasticity for disturbances in two ways.

\section{- Graphical Method}

After plotting the squares of the disturbances against the independent variable of inflation (any independent variable) due to the fluctuations in the figure, Heteroscedasticity is evident:

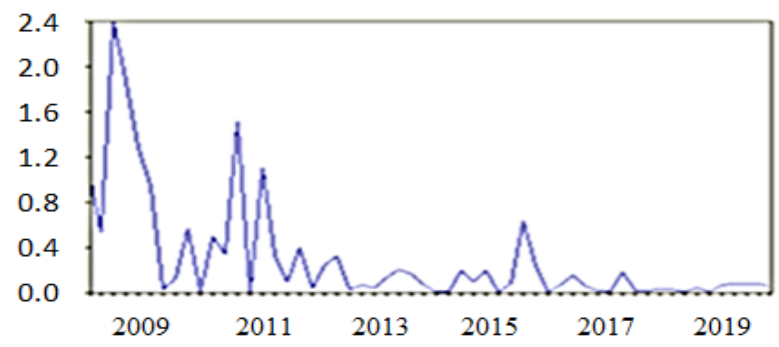

FIG. 2. Investigation of Homoscedasticity

\section{- White Test}

The white test uses to test the Homoscedasticity assumption of linear regression.

TABLE 5. White test results.

\begin{tabular}{|l|c|l|l|}
\hline F-statistic & 8.803858 & Probability & 0.000002 \\
\hline $\begin{array}{l}\text { Obs*R- } \\
\text { squared }\end{array}$ & 29.05131 & Probability & 0.000059 \\
\hline \multicolumn{4}{|c|}{ Ref: Field of Survey }
\end{tabular}

Considering that the P-value in the table above is less than 0.05 , it can be concluded that at a significance level of $5 \%$, the assumption of the null hypothesis, which indicates Homoscedasticity, is rejected and the alternative hypothesis, which indicates heteroscedasticity, is accepted.

\section{- Elimination of heteroscedasticity}

Although there is no single method for eliminating heteroscedasticity, the most common way to solve this problem in the model is to use the GLS method, which standardizes the variancecovariance matrix of the data. The result is as follows:

TABLE 6. Results after elimination of heteroscedasticity.

\begin{tabular}{|l|c|c|c|c|}
\hline \multicolumn{1}{|c|}{ Variable } & Coefficient & Std. Error & t-Statistic & Prob. \\
\hline LIQUIDITY & 1.125248 & 0.095018 & 11.84251 & 0.0000 \\
\hline INFLATION & -0.755926 & 0.282621 & -2.674700 & 0.0100 \\
\hline GDP & 0.428368 & 0.111917 & 3.827554 & 0.0003 \\
\hline C & -14.96406 & 1.002829 & -14.92185 & 0.0000 \\
\hline
\end{tabular}




\begin{tabular}{|l|l|l|l|}
\hline R-squared & 0.891742 & F-statistic & 142.7773 \\
\hline Adjusted R-squared & 0.885496 & Prob(F-statistic) & 0.000000 \\
\hline Durbin-Watson stat & 1.016176 & \\
\hline \multicolumn{2}{|c|}{ Ref: Field of Survey }
\end{tabular}

\section{- Existence of Autocorrelation}

The hypothesis of autocorrelation between the disturbances has been investigated using graphical methods and the LM test. Also, according to the number 1.016 for the DurbinWatson statistic, using the Durbin-Watson table, the existence of positive autocorrelation is confirmed.

\section{- Graphical Method}

It is assumed that in the regression models the estimated model disturbances are a good estimate for the behavior of the main model disturbances; so by drawing disturbances against time the presence or absence of autocorrelation in the model can be examined. According to the diagram and the fluctuations in the figure, autocorrelation is evident in the model:

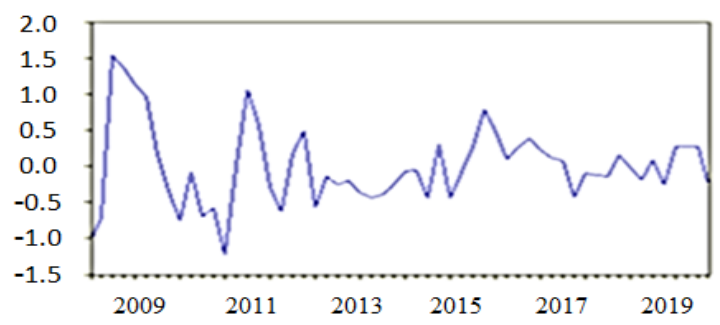

FIG.3. Study of Autocorrelation

\section{- LM Test}

In addition to the Durbin-Watson statistic, and diagram above, the LM test also confirms the existence of autocorrelation in the model. It should be noted that in the test, first-order autocorrelation was examined.

TABLE7. LM Test results.

\begin{tabular}{|l|c|l|l|}
\hline F-statistic & 14.60492 & Probability & 0.000362 \\
\hline $\begin{array}{l}\text { Obs*R- } \\
\text { squared }\end{array}$ & 12.46668 & Probability & 0.000414 \\
\hline \multicolumn{4}{|c|}{ Ref: Field of Survey } \\
\hline
\end{tabular}

Given that the $\mathrm{P}$-value $<0.05$, it can be concluded that at a significance level of $5 \%$, the null hypothesis, which refers to no autocorrelation, is rejected and the alternative hypothesis, which refers to the first-order autocorrelation in disturbances, is accepted. Therefore, it can be concluded that there is a relationship between successive errors. Errors of the one-time period correlate with the errors of the consequent time period.

\section{- Elimination of Autocorrelation}

Since autocorrelation can cause inefficiency in estimating model parameters, we use the comparison autocorrelation and partial correlation to remove autocorrelation. The results are shown in the figure below:

\begin{tabular}{|c|c|c|c|c|c|c|c|}
\hline Autocorr & elation & Partial Correlation & & $\mathrm{AC}$ & PAC & Q-Stat & Prob \\
\hline , & $\square$ & $\square$ & 1 & 0.460 & 0.460 & 12.519 & 0.000 \\
\hline $\mathrm{I}$ & 1 & 당 & 2 & 0.021 & -0.243 & 12.546 & 0.002 \\
\hline 10 & I & 1 & 3 & -0.120 & -0.027 & 13.428 & 0.004 \\
\hline 1 & 1 & I & 4 & -0.081 & 0.005 & 13.840 & 0.008 \\
\hline 1 & 1 & 10 & 5 & -0.118 & -0.136 & 14.726 & 0.012 \\
\hline 단 & 1 & ，目 & 6 & -0.219 & -0.161 & 17.842 & 0.007 \\
\hline (5 & 1 & 1 & 7 & -0.212 & -0.062 & 20.831 & 0.004 \\
\hline I & I & 10 & 8 & -0.160 & -0.107 & 22.566 & 0.004 \\
\hline 1 & 1 & 1 & 9 & -0.078 & -0.040 & 22.983 & 0.006 \\
\hline $\mathrm{I}$ & 1 & 1 & 10 & 0.034 & 0.040 & 23.063 & 0.011 \\
\hline 1 & I & 1 & 11 & 0.101 & 0.006 & 23.802 & 0.014 \\
\hline I & וב & a & 12 & 0.181 & 0.104 & 26.217 & 0.010 \\
\hline I & 1 & $\square$ & 13 & -0.004 & -0.235 & 26.219 & 0.016 \\
\hline 10 & I & 11 & 14 & -0.112 & -0.044 & 27.191 & 0.018 \\
\hline I & 1 & I & 15 & -0.053 & 0.023 & 27.414 & 0.026 \\
\hline I & 1 & 161 & 16 & 0.103 & 0.098 & 28.268 & 0.029 \\
\hline I & 1 & $1 \sqrt{1}$ & 17 & 0.076 & -0.044 & 28.745 & 0.037 \\
\hline
\end{tabular}

FIG.4.The trends of autocorrelation and partial correlation.

According to changes in autocorrelation and partial correlation, the first-order movingaverage (MA (1)) adds to the model in order to remove the first-order autocorrelation.

The final results of the nonlinear model are as follows: 
TABLE 8. Final Results.

\begin{tabular}{|l|l|l|l|l|}
\hline Variable & Coefficient & Std. Error & t-Statistic & Prob. \\
\hline LIQUIDITY & 1.133060 & 0.190229 & 5.956300 & 0.0000 \\
\hline INFLATION & -0.745501 & 0.301278 & -2.474465 & 0.0167 \\
\hline GDP & 0.417027 & 0.200339 & 2.081605 & 0.0424 \\
\hline C & -14.95942 & 1.805282 & -8.286476 & 0.0000 \\
\hline MA(1) & 0.497484 & 0.123416 & 4.00957 & 0.0002 \\
\hline R-squared & 0.918137 & F-statistic & 142.9980 \\
\hline Adjusted R-squared & 0.911716 & Prob(F-statistic) & 0.000000 \\
\hline Durbin-Watson stat & 1.796965 & \multicolumn{4}{l}{} \\
\hline
\end{tabular}

The value of the Watson-Durbin statistic is 1.79 , indicating no autocorrelation. The coefficients of the variables are also significant and considering the value of goodness of fit test coefficient (R-square), the variables explain $91.8 \% \approx 92 \%$ of the dependent variable behavior. According to the final table, the relationship between trading volume in TSE with the two variables of liquidity and GDP is positive and with inflation is negative; the final model is also defined as follows:

LnTurnover $=-14.959+0.417$ Ln GDP +1.133 Ln Liquidity -0.745 Ln Inflation

\section{CONCLUSION}

Today, the dynamic of the stock market is one of the indicators of the economic growth of countries and the volume of transactions in this market shows the public willingness to participate in it. Therefore, it is important to study the relationship between stock trading volume and macroeconomic variables in order to determine the impact of these variables on trading volume.

In this section, the results of the model explain for each variable. In the following, executive solutions to increase the dynamic of the Tehran stock market and finally suggestions for future studies will be presented.

\section{Liquidity}

Liquidity is the sum of banknotes, coins, and short-term and long-term deposits in the hands of the people. In Tehran, liquidity is distributed in three sectors, which include banks and financial institutions, the market and the stock exchange. Banks and financial institutions attract liquidity through short-term and long-term interest payments and financial facilities. The market is also divided into two parts, the false market and the real market. The false market attracts capital by buying and selling all kinds of goods, including coins, currencies, real estate transactions, cars, and the like. Due to the quick return of this sector and the lack of need for specialized knowledge, a large part of liquidity Existing in the society Overflow to such markets and cause high inflation. The real market is also a sector that includes long-term and productive investments. Despite governments' efforts to drive capital to real markets and to encourage consumerism in order to increase production and improve the economic cycle by increasing liquidity, this has led to rising inflation due to the inability to produce and forced the government to increase imports. According to these explanations, a part of the liquidity in the society always enters the stock market; and if the attraction and expected return increase in this market, more money overflows into this part. since 2002, the volume of transactions in the Tehran stock market increased sharply; it can be partly due to the increase in liquidity in the society, which for various reasons such as printing unsecured banknotes, providing shortterm and medium-term facilities, and increasing salaries. 
It also seems that with the arrival of investment companies, petrochemicals, and governmentaffiliated companies, the desire of people to participate in the stock market has increased and it has led to a significant increase in trading volume. In general, it can be said that more trust of investors led to a higher volume of transactions in the stock market and vice versa. As a result, with increasing liquidity, the volume of transactions on the stock exchange also increases.

\section{GDP}

Gross domestic product is the total value of goods and services produced annually in the country. The companies that are active in the stock exchange are either manufacturing or service. The higher gross domestic product shows the higher activities and consequently the increase in the volume of goods and services, and in a continuous economic system such as Iran, companies influence each other in such a way that an increase in the production will promote supply chain activities, and many industries will be involved in increasing productions and services; This, in turn, will increase sales and raised transactions. Thus, the positive psychological effect of this trading cycle and increasing its attractiveness, as well as the possibility of access to higher profits, causes the movement of capital to the stock exchange market and increases the trading volume.

\section{Inflation}

In economics, inflation means a continuous increase in the general price level of goods and services over a period of time. As we know, two important factors of investment attractiveness are the return of investment and the payback period.

Inflation devalues money over a period of time. Thus, if the stock market returns are higher than the inflation rate, stock exchange transactions will still be considered, but usually, because of the effects of inflation on the forecast of dividends for reasons such as shortages and high prices of raw materials, rising costs of wages, production, energy, and ultimately the increase in costs and the control of rates by the government the attractiveness of the stock market will be reduced. As inflation reflects the devaluation of money and, on the other hand, reduces the profitability of stocks, capital will move to a more attractive market. In times of inflation, the average person in the community turns to quick-return activities and prefers to make lower profits with less risk due to fluctuations in stock returns; Therefore, in inflationary periods, investments are propelled to banks and financial institutions, and thus the volume of transactions on the stock exchange is reduced, but due to the reduction of short-term and long-term investments of banks and financial institutions, and given the high inflation rate in this period, investors are more inclined to invest in quick-return markets such as gold, currency, automobiles and the capital market.

\section{REFERENCES}

1. Anirut. P.; Abeyratna. G. (2005). "The Causal and Dynamic Relationship between Stock Returns and Trading Volume: Evidence from Emerging market in South-East Asia”, Second International Business Research Conference, Sydney, Australia.

2. Arab Mazar, Abbas. (1990). General Econometrics, Tehran, Kavir Publications.

3. Barzani, Mohammad Vaez and Rahim Dalali Esfahani and Saeed Samadi and Hamid Reza Activist .(2007). "Assessing the supervisory role of the government in the Aidan Stock Exchange in the framework of an optimal control model", Economic Research Journal, Year 10, Issue 1, Spring 1989, pp. 307-285.

4. Bidram, Rasool .(2002). Synchronized with EViews econometrics, Tehran, Productivity Charter Publications. 
5. Chen, G.; Firth, M.; Rui. O.M .(2001). "The dynamic relation between stock returns, trading volume and volatility", Financial Review, 36, 153-173.

6. Christopher gan and et.al .(2006). "macroeconomic variables and stock market interactions: New Zealand evidence", the journal of investment management and financial innovation, 2006, pp.89101.

7. Daei Karimzadeh, Saeed, Sharifi Renani, Hossein and Lotfali Ghasemian Moghadam .(2013). The effect of macroeconomic variables on banks' stock price index, Economic Journal, (11), 65-90.

8. Duong. N.; and Robert. D .(2006). "A Return-Volume-Volatility Analysis of Futures Contracts", Journal of Financial Economics, 61, 43-76.

9. Fadaei Nejad and Farahani .(2017). The Effects of Macroeconomic Variables on the Total Index of Tehran Stock Exchange, Journal of Financial Economics, Volume 11, Number 39, Pages 1-26.

10. Fama, E.; \& French, K .(1993). "Common risk factors in the returns on stocks and bonds",Journal of Financial Economics, 33(1).

11. Hassanzadeh, A., \& Kianvand, M .(2012). The impact of macroeconomic variables on stock prices: The case of Tehran Stock Exchange. Journal of Money and Economy, 6(2), 171-190.

12. Kwon, C.S.T.S Shin .(1999). "Counteraction and Causality between Macroeconomic Variables and Stock Market Returns", Global Finance Journal, Vol. 10, No. 1, pp. 71-81.

13. Lee, B.; O. Rui .(2002). "The Dynamic Relationship between Stock Returns and Trading Volume: Domestic and Cross-Country Evidence", Journal of Banking and Finance, 26, 51-78.

14. Mashayekh, S., Moradkhani, H. H., \& Jafari, M.(2011). March, Impact of macroeconomic variables on stock market: The case of Iran. In 2nd International Conference on Business and Economic Research Proceeding, pp. 350-360.

15. Moosa, I.A.; Al-Loughani N.E. (1995). "Testing the price-volume relation in emerging Asian stock markets", Journal of Asian Economics, 6, 407-422.

16. Muradoglu; Yaz Gulnur; Metin; Kivilcim. (1996). Efficiency of the Turkish Stock Exchange with Respect to Monetary Variables: A Cointegration Analysis", European Journal of Operational Research, No. 90, PP. 566-576.

17. Nijam, H. M., Ismail, S. M. M., \& Musthafa, A. M. M. (2018). The impact of macro-economic variables on stock market performance; evidence from Sri Lanka. Journal of Emerging Trends in Economics and Management Sciences, 9(2), 115-121.

18. Ouma, W. N., \& Muriu, P. (2014). The impact of macroeconomic variables on stock market returns in Kenya. International Journal of Business and Commerce, 3(11), 1-31.

19. Sameti, Majid and Mahnaz Moradian Tehrani. (2007). "Study of the relationship between company value and inflation rate using Tobin index in Tehran Stock Exchange during the period 1373-83", Quarterly Journal of Economic Studies, No. 3, pp. 60-45. 